
\title{
28 Research Square \\ Unmet Need for Healthcare Among People with Hypertension in Indonesia
}

Asmaripa Ainy ( $\sim$ asmaripa_ainy@fkm.unsri.ac.id)

Faculty of Public Health Sriwijaya University https://orcid.org/0000-0002-2769-3885

Amrina Rosyada

Universitas Sriwijaya

Haerawati Idris

Universitas Sriwijaya

\section{Asri Maharani}

The University of Manchester

\section{Research article}

Keywords: unmet need, healthcare, hypertension, Indonesia, IFLS-5

Posted Date: August 3rd, 2020

DOl: https://doi.org/10.21203/rs.3.rs-50632/v1

License: (9) This work is licensed under a Creative Commons Attribution 4.0 International License. Read Full License 


\section{Abstract}

Background: Hypertension is a leading global public health problem in both developed and developing countries including Indonesia, mainly due to its high frequency and risks of cardiovascular diseases. Prevalence of hypertension in the Indonesian population aged $>18$ years in 2018 was $34.11 \%$. Unmet need for healthcare generally has been explored, but limited empirical study explores it among people with hypertension. The objective of this study is to investigate the determinants of unmet need for healthcare among people with hypertension.

Methods: The design of this study is cross-sectional, using the data from the Indonesia Family Life Survey wave 5 (IFLS-5). The sample of the survey was 6,302 adults age $>40$ years old, stratified by rural/urban status. Three-level multilevel analysis was performed to estimate the individual level, household level, and community-level determinants of unmet needs for hypertension care.

Results: The data shows that $78.4 \%$ of respondents with hypertension reported an unmet need for healthcare. Age, female, single, income, having insurance, living in the urban area, and the number of health posts for elderly (Posyandu Lansia) are significantly associated with meet needs for health care utilization among hypertension, while education and employment status shows no association with them.

Conclusion: Improving access to healthcare and reducing health inequality are required to address this problem.

\section{Background}

Hypertension is regarded as a global public health problem in both developed and developing countries because of its high prevalence and contribution to the burden of cardiovascular disease(1). Hypertension is a major factor for noncommunicable diseases (NCDs) that continues to increase. NCDs in Indonesia are estimated to account for $73 \%$ of all deaths in 2016 and one of its major risk factors at adults aged 18 + was raised blood pressure (22\%)(2) According to Indonesian Basic Health Research (Riskesdas) in 2018 estimated the prevalence of hypertension in the Indonesian population aged $18+$ was $34.11(3)$. The prevalence of hypertension has become a significant factor for contributing worldwide mortality and morbidity(4)(5). It gradually damaged the heart, blood vessels, and other organs without apparent symptoms and recognized as a silent killer(5). People with resistant hypertension are more likely to be older, overweight, have diabetes, and have a long history of poorly controlled blood pressure(6).

Therefore, prevention and control of NCDs become one of the national priority programs in the health sector in Indonesia. In 2016, the Indonesian ministry of health issued a national program called Healthy Indonesia approached by Family $(P I S-P K)(7)$. The success of this program is measured by the Healthy Family Index (IKS) formulated from four national priority health programs in Indonesia, namely reducing maternal mortality, reducing infant mortality and stunting prevalence, controlling communicable diseases 
(HIV/AIDS, tuberculosis and malaria) and controlling NCDs (Hypertension, Diabetes Mellitus, Cancer, Obesity and Mental Disorders)(8).

Unmet need for health care is an undesirable feature of modern health care(9). A recent study regarding hypertension among Indonesian adults aged 40-65 years using IFLS-4 in 2007 datasets described that there was a low prevalence of antihypertensive medication treatment. The research stated that $37 \%$ of people with hypertension were diagnosed or aware and only $25 \%$ were treated with prescribed antihypertensive medication(10). Other studies have discussed the problem of access to health services influenced by various factors, such as reduction in consumer trust in hospital in-patient services, lack of continuity in the health system, culture and resource, inconvenient timing of appointments and the longterm implications of accessing healthcare(11)(12)(13)(14). Moreover, personal choice, waiting time, and cost become contributing factors to unmet need health care(15)(16)(17)(18). Generally, unmet health care needs depend on the aspects of the health care system (timing of appointments, waiting time before receiving care, etc.) and in certain situations of individuals seeking care (personal choice, trust, cost, etc). However, there is a limited study that explores the unmet need for healthcare among people with hypertension.

\section{Methods}

In this research, a cross-sectional study was conducted based on The Indonesian Family Life Survey Wave 5 (IFLS-5) database, which was fielded on the full sample in 2014-2015. IFLS5 contains detailed information collected at the individual and household levels, including multiple indicators of socioeconomics and health. It is the only large-scale longitudinal survey available for Indonesia and conducted by multistage random sampling method, which was conducted in 13 Provinces representing $83 \%$ of the population in Indonesia(19).

We included respondents aged 40 years and older and had hypertension categorized by measurement systolic $>140 \mathrm{mmhg}$ or diastolic $>90 \mathrm{mmhg}$ on 3 times the measurement of blood pressure. Based on the inclusion criteria, a sample of 6302 people was obtained. The dependent variable in this study is the number of unmet need for health services. The definition of unmet need for health services is if the respondent has hypertension but does not access health services such as primary health care, clinics and hospitals in the last 4 weeks.

\section{Covariates}

We use some variable to investigate unmet need health care based on socio-economic and demographic status at the level individual. Economic status was measured from variable log household expenditure and the number of health post for elderly (Posyandu Lansia) at the community level. Posyandu lansia is a community-organised health promotion centre at village level supervised by staff from the nearest community health centre. Since the mid-1980s, the Indonesia Ministry of Health has launched services to older people through Posyandu Lansia. To deal with the increasing prevalence of hypertension and other chronic conditions, several preventive and health promotion activities are provided by local communities 
through Posyandu Lansia(20). Older people frequently obtained anti-hypertensive medications (26\%) through community health centers performed by its health staff members (midwives or nurses)(21). Other covariates at the individual level are age, sex (female and male as reference), educational attainment (primary school or less as reference; secondary class; and college or higher), marital status (married as reference; single; divorced,and widower), employment status (casual workers as reference; government workers; private workers; self-employed, and not working), health insurance ownership. We also provide the descriptive statistics of age categorized in eight groups (40-44, 45-49, 50-54, 55-59, 60$64,65-69,70-74,+75)$,

\section{Statistical analysis}

We conducted data analysis in two steps: bivariate analysis and multivariate analysis. The bivariate analysis assessed the relationship between two variables: 1) the area of residence and 2) each of its determinants (separately). We used Kruskal-Wallis one-way analysis of variance for numerical variables and ordinal chi-square tests for categorical variables. The multivariate analysis identified the association between the healthcare utilization and all of the risk factors together using tree-level hierarchical logistic regression models to take into account of the household and community level information available from the IFLS. The first level comprised individual characteristics, the second level was household characteristics, and community characteristics made up the third level. Considering individual $i$ nested in a household, and community $k$.

$Y_{i j k}=\gamma_{000}+\sum \gamma_{00 k} U_{k}+\sum \gamma_{0 j k} W_{j k}+\sum \beta_{i j k} X_{i j k}+u_{00 j}+r_{0 j k}+\epsilon_{i j k}$

with:

$Y_{i j k}=$ cognitive function as an ordinal variable (normal, CIND and dementia) for the individual in household $j$ in community $k$.

$U_{k}$ is a set of community characteristics,

$W_{j k}$ is a set of household and community characteristics,

$X_{i j k}$ is a set of individual characteristics,

$u_{00 j}$ are the random intercept varying over the household

$r_{0 j k}$ is the random intercept varying over household and community

$\epsilon_{i j k}$ is normally distributed with mean zero and variance $\sigma_{\epsilon}{ }^{2}$.

The multivariate analysis used two models. The first model included only the individual-level variables, including socio-demographic variables of age, gender, marital status, education, employment status, and health insurance ownership. We added the household expenditure as the household level determinant, and rural/urban category and the number of Posyandu Lansia as the community level determinants in 
the second model. We conducted the hierarchical logit regression using xtmelogitcommands in STATA 14.0 software(22).

\section{Results}

A total of 6,302 respondents aged 40 years and over were initially included in this study. About $78.4 \%$ of respondents with hypertension did not receive healthcare service (see table 1). The average respondent's age was 57 years old. $16.80 \%$ of respondents were $50-54$ years old. More than half of the respondents $(56.50 \%)$ were female. Most of the respondents had low education attainment (63.4\%), married (74.3\%), not working (90.7\%), and have no health insurance (54.24\%). Household expenditure Rp 953,005.12 (Rp 606,991.47) for total, Rp 968,233.01 (Rp 779,509.13) for urban area and Rp 932,716.29 (Rp 221,659.79) for rural area. The average numbers of PosyanduLansia per village were 2.

The bivariate logistic regression model in table 1 shows that four predictions are statistically significant, with met needs at $1 \%$ level.The proportion of respondent with unmet need in urban is higher than rural.At the individual level, age, educational level, employment status, having insurance all correlate positively with met needs. Household expenditure is statistically significant, with met needs at $5 \%$ level. Sex and marital status are elements that both fail to achieve statistical significance.

Factors associated with unmet healthcare, as revealed by the multivariate analysis, are presented in table 2. Older age is associated with lower odds of having unmet need of healthcare services (Odds Ratio=0.987; $p<0.001)$ in the first model, but this association is diminished after household and community level variable were included in the second model $(O R=0.989 ; p<0.05)$. Being female and having health insurance has negative and significant associations with the unmet need for healthcare services. Single respondents have higher odds of having unmet needs of healthcare services than married respondents. Respondents living in urban areas have lower odds of having unmet needs of healthcare services than those living in urban areas $(O R=0.774 ; p<0.001)$. The number of PosyanduLansia in the community has a negative and significant association with the unmet need of healthcare services $(\mathrm{OR}=0.72 ; \mathrm{p}<0.001)$. 
Table 1

Characteristics of the participants

\begin{tabular}{|c|c|c|c|c|}
\hline & $\begin{array}{l}\text { Total } \\
n=6,302\end{array}$ & $\begin{array}{l}\text { Urban } \\
n=3,600\end{array}$ & $\begin{array}{l}\text { Rural } \\
n=2,702\end{array}$ & $\begin{array}{l}\mathrm{P} \text { - } \\
\text { value }\end{array}$ \\
\hline \multicolumn{5}{|l|}{ Individual-level } \\
\hline $\begin{array}{l}\text { Healthcare } \\
\text { utilization }\end{array}$ & & & & $\begin{array}{l}<.001 \\
0.001\end{array}$ \\
\hline No & $4,940(78.40)$ & 2,757 & 2,183 & \\
\hline Yes & $1362(21.60)$ & 843 & 519 & \\
\hline Age (years) & $57.17(16.62)$ & $56.53(19.31)$ & $58.02(12.10)$ & $\begin{array}{l}<.001 \\
0.001\end{array}$ \\
\hline Age group & & & & $\begin{array}{l}< \\
0.001\end{array}$ \\
\hline $40-44$ & $929(14.70)$ & 565 & 364 & \\
\hline $45-49$ & $1038(16.50)$ & 621 & 417 & \\
\hline $50-54$ & $1,056(16.80)$ & 602 & 454 & \\
\hline $55-59$ & $896(14.20)$ & 537 & 359 & \\
\hline $60-64$ & $823(13.10)$ & 476 & 347 & \\
\hline $65-69$ & $504(8.00)$ & 284 & 220 & \\
\hline $70-74$ & $498(7.90)$ & 251 & 247 & \\
\hline $75+$ & $558(8.90)$ & 264 & 294 & \\
\hline Sex & & & & 0.730 \\
\hline Male & $2,741(43.50)$ & 1,573 & 1,168 & \\
\hline Female & $3,561(56.50)$ & 2,027 & 1,534 & \\
\hline Educational level & & & & $\begin{array}{l}< \\
0.001\end{array}$ \\
\hline $\begin{array}{l}\text { Primary school or } \\
\text { less }\end{array}$ & $3998(63.4)$ & 1901 & 2097 & \\
\hline Secondary school & 1807 (28.7) & 1330 & 477 & \\
\hline College or higher & $497(7.9)$ & 369 & 128 & \\
\hline Marital status & & & & 0.068 \\
\hline
\end{tabular}

Note: Presented are mean (SD) or number (\%) 


\begin{tabular}{|c|c|c|c|c|}
\hline & $\begin{array}{l}\text { Total } \\
n=6,302\end{array}$ & $\begin{array}{l}\text { Urban } \\
n=3,600\end{array}$ & $\begin{array}{l}\text { Rural } \\
n=2,702\end{array}$ & $\begin{array}{l}\mathrm{P} \text { - } \\
\text { value }\end{array}$ \\
\hline Single & $118(1.9)$ & 80 & 38 & \\
\hline Married & $4682(74.3)$ & 2687 & 2004 & \\
\hline Divorced & $1471(23.3)$ & 822 & 649 & \\
\hline Widower & $31(0.5)$ & 20 & 11 & \\
\hline Employment status & & & & $\begin{array}{l}< \\
0.001\end{array}$ \\
\hline Casual workers & $53(0.8)$ & 25 & 28 & \\
\hline Government workers & $81(1.3)$ & 69 & 12 & \\
\hline Private workers & 209 (3.3) & 177 & 32 & \\
\hline Self-employed & $241(3.8)$ & 124 & 117 & \\
\hline Not working & $5718(90.7)$ & 3205 & 2513 & \\
\hline $\begin{array}{l}\text { Health insurance } \\
\text { ownership }\end{array}$ & & & & $<0.001$ \\
\hline No & $3,226(54.24)$ & 1,563 & 1,663 & \\
\hline Yes & $3,076(45.76)$ & 2,037 & 1,039 & \\
\hline $\begin{array}{l}\text { Mean systolic BP } \\
(\mathrm{mmHg})\end{array}$ & $161.23(21.26)$ & 160.68 (21.18) & 162.00 (21.35) & 0.015 \\
\hline $\begin{array}{l}\text { Mean diastolic BP } \\
(\mathrm{mmHg})\end{array}$ & $92.41(12.62)$ & 92.94 (12.19) & $91.71(13.13)$ & $<0.001$ \\
\hline \multicolumn{5}{|l|}{ Household-level } \\
\hline $\begin{array}{l}\text { Household } \\
\text { expenditure }\end{array}$ & $\begin{array}{l}953,005.12 \\
(606,991.47)\end{array}$ & $\begin{array}{l}968,233.01 \\
(779,509.13)\end{array}$ & $932,716.29(221,659.79)$ & 0.009 \\
\hline Community-level & & & & - \\
\hline $\begin{array}{l}\text { Number of } \\
\text { Posyandu Lansia }\end{array}$ & $2(0.00)$ & $2(0.00)$ & $2(0.00)$ & \\
\hline
\end{tabular}


Table 2

Determinants of unmet need of healthcare services among sample with hypertension

Model 1

Model 2

Individual-level

Age

$0.987(0.003) \ddagger$

$0.989(0.004) \dagger$

Female

$0.600(0.046) \ddagger$

$0.638(0.059) \ddagger$

Marital status, reference: married

Single

$5.201(2.305) \ddagger$

6.941 (3.802)‡

Divorced

$1.150(0.108)$

$1.192(0.132)$

Widower

$2.086(1.223)$

$3.502(2.855)$

Education, reference: primary

Secondary

$0.930(0.079)$

$1.004(0.109)$

College and higher

$1.024(0.144)$

$1.298(0.265)$

Employment status, reference: Casual workers

Government workers

$1.136(0.520)$

$1.428(0.779)$

Private workers

$1.118(0.445)$

$1.352(0.600)$

Self-employed

$0.950(0.368)$

1.205 (0.501)

Not working

1.297 (0.463)

$1.950(0.744)^{*}$

Having insurance

$0.693(0.051) \ddagger$

$0.721(0.065) \ddagger$

Household-level

Log household expenditure

$0.610(0.044) \ddagger$

Community-level

Living in an urban area

$0.774(0.084) \dagger$

Number of Posyandu Lansia

0.864 (0.048)‡

Constant

11.290 (5.055)‡

8116.32 (9112.02)‡

Variance between households

0.18

0.17

Variance between communities

0.57

0.72

Log-likelihood

35.63

27.85

Note: Reported are odds ratios (standard errors). Sig.: *significant at $10 \%$ or less; tsignificant at $5 \%$ or less; $¥$ significant at $1 \%$ or less. 


\section{Discussion}

Hypertension is one of the NCDs that is commonly found in developing countries, including Indonesia. Therefore, Indonesia Ministry of Health launched a programme concerning the implementation of PIS-PK in 2016 and hypertension care is one indicator of the healthy family. Various studies have reported the risk factors of hypertension. Previous research has shown that at a university student in Thailand, older age, obesity and underlying morbidity due to diabetes, high blood lipids and kidney disease were strongly associated with increased risk of incident hypertension(23). Other similar research revealed that hypertension in the urban slum Nairobi, Kenya is a public health problem affecting at least one in three adults aged 35-64 years and several variables, such as age, marital status, wealth index, physical inactivity and body mass index are important risk factors associated with hypertension(24). An analysis of the SAGE dataset from households within China, Ghana, India, Mexico, Russia, and South Africa, illustrated that obesity emerged as a noticeably common correlate to hypertension, along with increasing age(25). This also found from a study in Varanasi, India that increasing age and sex (specifically men) are proved to be independent risk factors for hypertension(26). Other protective risk factors of hypertension among urban residents were being unemployed retired and student status(27).

Several national studies investigate the determinant of unmet need for healthcare among people with hypertension in Indonesia. Using a recent national survey, it was identified that poor access to healthcare facilities become one of the determinant factors(28). This study shows that unmet healthcare found in more than three-quarter of people with hypertension in Indonesia. At the level of the individual, age, being female, and having health insurance is an important determinant in explaining in unmet need healthcare among people with hypertension. Age has a positive correlation with having met a need for health care. The increasing number of health problems with age, which increasesthe probability of having unmet health care needs(29). Female have a higher likelihood of healthcare care than male. Previous research described a higher number of unmet healthcare needs among females(30)(31). Having health insurance has a positive correlation with unmet need health care. The study shows that respondents who have health insurance are more likely to receive healthcare. The previous research shows that uninsured respondent who adults are significantly more likely to have unmet needs for preventive services than insured adults(32).

This is the first study to report on factors associated with unmet need for healthcare among people with hypertension in Indonesia using national survey datasets. Focusing on household determinants, we found that household expenditure is an important determinant in explaining unmet need healthcare among people with hypertension. This result supports findings from the previous study that the poor individual increases the risk of having unmet need healthcare(33).

Turning to community-level determinants, living in urban and number of Posyandu Lansia in the community are important determinants in explaining in met need healthcare among people with hypertension. Focus on the residency areas, living in an urban area is correlated with a lower probability of having unmet need health care. Furthermore, this study shows that the respondent who has to live in 
urban are more likely to receive healthcare services. The findings in this study are consistent with the previous research which found that residing in urban area is significantly associated with the met need for cardiovascular(33)(33)(32)(31)(30)(29)(28)(34). The number of Posyandu Lansia in the community has a positive correlation with met need health care. The availability of healthcare facilities is one of the factors contributing to unmet health care(35). The previous study mentioned that individual perception of healthcare availability plays an important factor in the experience of unmet healthcare needs(36).

This study has some limitations. Firstly, it used a cross-sectional design therefore, the observed associations cannot be assumed to be causal. Secondly, some variable that may affect the unmet need healthcare services cannot explore due to the unavailability of the data, such as the quality of healthcare. Quality of healthcare is an important element to explain unmet need healthcare. Several previous studies showed that perception of health care quality as a possible factor associated with demand for health care(31)(37)(38).

Despite its limitations, this study has several strengths. Firstly, we used a nationally representative sample from a population-based survey that has high response rate and use standardized methodology. Secondly, included in this survey are not only individual-level or household-level determinants but also factors at the community level. Our study can thus capture real conditions of the population using multilevel modelling analysis, which allows us to examine the clustering effect of the outcome variables.

\section{Conclusion}

This study revealed determinants of unmet need for healthcare among people with hypertension at the individual, household and community levels in Indonesia. With a multilevel regression analysis, we found that the unmet needs for health care among people with hypertension is still prevalent in Indonesia. The Indonesian government should improve equity in healthcare by expanding health insurance, provide availability number of Posyandu Lansia, and distribute healthcare service need both rural and urban. Future studies are required to understand other factors associated with healthcare utilization among people with hypertension, in particular how the role of cadres, family and health workers may have an association with their demand to healthcare.

\section{List Of Abbreviations}

NCDs: Noncommunicable diseases; Riskesdas: Riset Kesehatan Dasar; PIS-PK; Program Indonesia Sehat dengan Pendekatan Keluarga; IKS: Indeks Keluarga Sehat; HIV/AIDS: human immunodeficiency virus/acquired immune deficiency syndrome; IFLS-5: Indonesia Family Life Survey 5; Posyandu Lansia: Pos Pelayanan Terpadu bagi Lanjut Usia.

\section{Declarations}

\section{Ethics approval and consent to participate}


The primary data in this study was taken from the IFLS-5, a survey conducted and made freely available by RAND Corporation with the help from a non-government research agency Surveymeter. The IFLS-5 and their procedures were properly reviewed and approved by IRBs (Institutional Review Boards) in the United States (at RAND) and in Indonesia at the University of Gadjah Mada (UGM). This study has passed the ethics review from the Ethics Review Center of the Faculty of Public Health, Sriwijaya University, with a letter of ethical qualification No. 176/UN9.1.10/KKE/2020.

\section{Consent for publication}

Not applicable.

\section{Availability of data and materials}

The datasets generated and/or analyzed during the current study are freely available in the RAND repository, https://www.rand.org/labor/FLS/IFLS.html

\section{Competing interests}

The authors declare that they have no competing interests.

\section{Funding}

This research received no specific grant from any funding agency in the public, commercial, or not-forprofit sectors

\section{Authors' contributions}

AA and AM conceptualized the study design and contributed to smoothing out the text. AR and AM acquired the raw data for analysis and performed data interpretation. AA and $\mathrm{HI}$ conceptualized for the article then prepared the original draft of the manuscript. All authors read and approved the final manuscript.

\section{Acknowledgements}

The authors are thankful for RAND that provides access to survey data in IFLS-5. We are grateful for participants who provided the survey data. The data sets used during the current study is freely available to the general public by request at https://www.rand.org/well-being/social-and-behavioralpolicy/data/FLS/IFLS/ifls5.html

\section{References}

1. Shah N, Shah Q, Shah AJ. The burden and high prevalence of hypertension in Pakistani adolescents: A meta-analysis of the published studies. Arch Public Heal. 2018;76(1):1-10. 
2. World Health Organization. Noncommunicable Disease Country Profiles 2018. World Health Oragnization. Switzerland; 2018.

3. Penelitian dan Pengembangan Kesehatan Kementerian Kesehatan RI. Laporan Riskesdas 2018 [Internet]. Vol. 53, Journal of Chemical Information and Modeling. 2018. Available from: http://www.yankes.kemkes.go.id/assets/downloads/PMK No. 57 Tahun 2013 tentang PTRM.pdf

4. Ezzati M, Lopez AD, Rodgers A, Vander Hoorn S, Murray CJL. Selected major risk factors and global and regional burden of disease. Lancet. 2002;360(9343):1347-60.

5. Yano Y, Reis JP, Colangelo LA, Shimbo D, Viera AJ, Allen NB, et al. Association of Blood Pressure Classification in Young Adults Using the 2017 American College of Cardiology/American Heart Association Blood Pressure Guideline with Cardiovascular Events Later in Life. JAMA - J Am Med Assoc. 2018;320(17):1774-82.

6. Williams B. Resistant hypertension: an unmet treatment need. Lancet. 2009;374(9699):1396-8.

7. Departemen Kesehatan RI. Undang - Undang No. 39 Tahun 2009 tentang Kesehatan. 2009.

8. Kementrian Kesehatan Republik Indonesia. Pedoman Umum Program Indonesia Sehat dengan Pendekatan Keluarga [Internet]. J: Kementrian Kesehatan Rl; 2016. Available from: http://dx.doi.org/10.1016/j.jsames.2011.03.003\%0Ahttps://doi.org/10.1016/ j.gr.2017.08.001\%0Ahttp://dx.doi.org/10.1016/ j.precamres.2014.12.018\%0Ahttp://dx.doi.org/10.1016/j.precamres.2011.08.005\%0 Ahttp://dx.doi.org/10.1080/00206814.2014.902757\%0Ahttp://dx.doi.org/10

9. Krůtilová V. Unmet Need For Health Care - A Serious Issue for European Elderly? Procedia - Soc Behav Sci. 2016;220:217-25.

10. Hussain MA, Al Mamun A, Reid C, Huxley RR. Prevalence, awareness, treatment and control of hypertension in Indonesian adults aged $\geq 40$ years: Findings from the Indonesia Family Life Survey (IFLS). PLoS One. 2016;11(8):1-16.

11. Awofeso N, Rammohan A, Asmaripa A. Exploring Indonesia's "low hospital bed utilization-low bed occupancy-high disease burden" paradox. J Hosp Adm. 2012;2(1):49-58.

12. Meiqari L, Nguyen TPL, Essink D, Zweekhorst M, Wright P, Scheele F. Access to hypertension care and services in primary health-care settings in Vietnam: a systematic narrative review of existing literature. Glob Health Action. 2019;12(1):1610253.

13. Adedini SA, Odimegwu C, Bamiwuye O, Fadeyibi O, De Wet N. Barriers to accessing health care in Nigeria: Implications for child survival. Glob Health Action. 2014;7(1):1-10.

14. Turner RA, Szaboova L, Williams G. Constraints to healthcare access among commercial fishers. Soc Sci Med. 2018;216(September):10-9.

15. Allin S, Grignon M, Le Grand J. Subjective unmet need and utilization of health care services in Canada: What are the equity implications? Soc Sci Med. 2010;70(3):465-72.

16. Connolly S, Wren MA. Unmet healthcare needs in Ireland: Analysis using the EU-SILC survey. Health Policy (New York). 2017;121(4):434-41. 
17. Shi L, Stevens GD. Vulnerability and unmet health care needs: The influence of multiple risk factors. J Gen Intern Med. 2005;20(2):148-54.

18. Sanmartin C, Houle C, Tremblay S, Berthelot JM. Changes in unmet health care needs. Health Rep. 2002;13(3):15-21.

19. Strauss J, Witoelar F, Sikoki B. The Fifth Wave of the Indonesia Family Life Survey: Overview and Field Report: Volume 1. Fifth Wave Indones Fam Life Surv Overv F Rep Vol 1. 2016;1(March).

20. Madyaningrum E, Chuang YC, Chuang KY. Factors associated with the use of outpatient services among the elderly in Indonesia. BMC Health Serv Res. 2018;18(1):707.

21. College RD, Deer R. Original Research Abstract: Keywords: Full Article: 2017;203(October 2018).

22. Wolfe R. Gn0031 Review Rabe Hesket Ggllamm.Pdf. 2006;(1):138-43.

23. Thawornchaisit P, De Looze F, Reid CM, Seubsman SA, Sleigh AC, Chokhanapitak J, et al. Health risk factors and the incidence of hypertension: 4-Year prospective findings from a national cohort of 60 569 Thai Open University students. BMJ Open. 2013;3(6):1-10.

24. Olack B, Wabwire-Mangen F, Smeeth L, Montgomery JM, Kiwanuka N, Breiman RF. Risk factors of hypertension among adults aged 35-64 years living in an urban slum Nairobi, Kenya. BMC Public Health. 2015;15(1):1-9.

25. Basu S, Millett C. Social epidemiology of hypertension in middle-income countries: Determinants of prevalence, diagnosis, treatment, and control in the WHO SAGE study. Hypertension. 2013;62(1):1826.

26. Singh S, Shankar R, Singh GP. Prevalence and Associated Risk Factors of Hypertension: A CrossSectional Study in Urban Varanasi. Int J Hypertens. 2017;2017.

27. Wang J, Sun W, Wells GA, Li Z, Li T, Wu J, et al. Differences in prevalence of hypertension and associated risk factors in urban and rural residents of the Northeastern region of the people's republic of China: A cross-sectional study. PLoS One. 2018;13(4):1-14.

28. Ibrahim MM, Damasceno A. Hypertension in developing countries. Lancet. 2012;380(9841):611-9.

29. Herr M, Arvieu JJ, Aegerter P, Robine JM, Ankri J. Unmet health care needs of older people: Prevalence and predictors in a French cross-sectional survey. Eur J Public Health. 2013;24(5):80813.

30. Nelson CH, Park J. The nature and correlates of unmet health care needs in Ontario, Canada. Soc Sci Med. 2006;62(9):2291-300.

31. Pappa E, Kontodimopoulos N, Papadopoulos A, Tountas Y, Niakas D. Investigating unmet health needs in primary health care services in a representative sample of the Greek population. Int $\mathrm{J}$ Environ Res Public Health. 2013;10(5):2017-27.

32. Ayanian JZ, Weissman JS, Schneider EC, Ginsburg JA, Zaslavsky AM. Unmet health needs of uninsured adults in the United States. J Am Med Assoc. 2000;284(16):2061-9.

33. Heo J, Oh J, Kim J, Lee M, Lee J seok, Kwon S, et al. Poverty in the Midst of Plenty: Unmet Needs and Distribution of Health Care Resources in South Korea. PLoS One. 2012;7(11). 
34. Maharani A, Tampubolon G. Unmet needs for cardiovascular care in Indonesia. PLoS One. 2014;9(8):1-10.

35. Diwan S, Moriarty D. A Conceptual Framework For Identifying Unmet Health Care Needs of Community Dwelling Elderly. J Appl Gerontol. 1995;14(1):47-63.

36. Hwang J, Guilcher SJT, Mclsaac KE, Matheson FI, Glazier R, O'Campo P. An examination of perceived health care availability and unmet health care need in the City of Toronto, Ontario, Canada. Can $\mathrm{J}$ Public Heal. 2017;108(1):e7-13.

37. Liu Y, Kong Q, Yuan S, Van De Klundert J. Factors influencing choice of health system access level in China: A systematic review. PLoS One. 2018;13(8):1-21.

38. Wellay T, Gebreslassie M, Mesele M, Gebretinsae H, Ayele B, Tewelde A, et al. Demand for health care service and associated factors among patients in the community of Tsegedie District, Northern Ethiopia. BMC Health Serv Res. 2018;18(1):697. 